\title{
Het conflict tussen Willem Bardes en Hendrick Dirckszoon
}

\section{J. J. WOLTJER}

Pieter Corneliszoon Hooft heeft in zijn pregnante stijl verhaald, hoe Willem Dirckszoon Bardes, schout van Amsterdam, en mr. Hendrick Dirckszoon, de leidende burgemeester van deze stad, een verbeten strijd om de macht voerden. Dit verhaal is met enige wijzigingen en aanvullingen van ondergeschikt belang overgenomen door Ter Gouw, Elias en anderen ${ }^{1}$. Hendrick Dircksz, zo vertellen deze schrijvers, haatte de schout bitter. Hij zocht zijn tegenstander te treffen door hem en zijn familie van sympathie voor en heulen met de Wederdopers te beschuldigen. Daartoe kocht hij omstreeks 1552 met medewerking van de pastoor, heer Floris Egbertszoon, een aantal getuigen om. Deze boze opzet kwam echter in de loop van een langdurig proces aan het licht en niet de schout, maar de valse getuigen, de burgemeester en de pastoor waren weldra de verdachten en werden vroeger of later gevangen genomen. Het Hof van Holland veroordeelde in 1562 een van deze valse getuigen ter dood, 'zekere vrouw, van Zwol geboren, met name Fy Hermans, die mits d'uitwendige gedaante haar innerlijke lelijkheid niet logende, om d'afzichtigheid haarder verwe in de wandelingen doorgaans Gele Fy geheten werd'. Twee anderen kregen lichtere straffen, de pastoor werd uit Amsterdam verbannen, maar de burgemeester ontsprong de dans, daar hij gezorgd had dat er geen bewijsmateriaal tegen hem was. Nadat Hendrick Dircksz bij gebrek aan bewijs was vrijgesproken, werd de strijd om de macht in Amsterdam voortgezet. Schout Bardes, vroeger een streng ketterjager, schroomde nu niet aansluiting te zoeken bij een voornamelijk uit Gereformeerden bestaande groep medeburgers ${ }^{2}$.

Het is een fraai verhaal. Na zijn veroordeling in 1562 verdwijnt de pastoor uit het gezichtsveld van de Hollandse historici, prijsgegeven aan de vergetelheid, zoals een minderwaardig banneling betaamt. Toch is zijn verder lot niet zonder betekenis. Heer Floris vertrok naar het zuiden en werd pastoor van de Sinte Goedele in Brussel. Zo leidde zijn verbanning tot een aanzienlijke promotie! Wilhelmus Lindanus, enige jaren inquisiteur in Holland en later bisschop van Roermond en Gent, be-

1. P. c. HOOFT, Nederlandsche Historiën (3e dr.; Amsterdam, 1677) 56-62; j. TER GOUW, Geschiedenis van Amsterdam (8 din; Amsterdam, 1879-1893) IV, 431^148 met bijlagen 491-504 en VI, 35-37; j. E. ELIAS, Geschiedenis van het Amsterdamsche regentenpatriciaat ('s-Gravenhage, 1923) $6-9$.

2. ELIAS, Regentenpatriciaat, 8.

178

BMGN 86 afl. 2. 
schouwde hem niet als een intrigant, maar als een martelaar, een 'heilige man Gods, een onoverwonnen voorvechter van het Katholiek geloof' en fra Lorenzo de Villavicentio noemde hem een bekend vijand van de ketters ${ }^{3}$. Hebben de collatoren van de Sinte Goedele, hebben Lindanus en fra Lorenzo de man fout beoordeeld? Of geeft het traditionele verhaal slechts een karikatuur van de werkelijke gebeurtenissen? Volgens Hooft en zijn navolgers was het conflict zuiver en alleen een strijd om de macht, met alle mogelijke middelen uitgevochten. De machtsstrijd tussen schout en burgemeester en een sterke persoonlijke rivaliteit spelen stellig een grote rol, maar toch menen wij, dat dit conflict tevens gezien moet worden als een symptoom van de spanningen waartoe de vervolging der ketters door Karel V en Philips II reeds in de jaren vijftig geleid heeft. Maar laten we niet op de conclusie vooruitlopen en beginnen met het verhaal zo nauwkeurig mogelijk te reconstrueren.

De bronnen zijn schaars. De dossiers van de processen, tot zulk een omvang gegroeid dat het Hof een apart tonnetje liet maken om ze te verzenden ${ }^{4}$, zijn niet teruggevonden en moeten als verloren worden beschouwd. Behalve de vonnissen van het Hof van Holland zijn slechts zeer kleine fragmenten bewaard. In de bibliotheek van het Gemeentearchief te Amsterdam berust een bundeltje ${ }^{5}$ met afschriften (o.a. van een rekest van Fye) en excerpten, terwijl C. Commelin in zijn Beschrijving van Amsterdam ${ }^{6}$ een fragment van een brief van het Hof van Holland, een fragment van een rekest van Volckje Willemsdr en enige excerpten van processtukken afdrukt. Helaas zijn, zoals zal blijken, de verklaringen van Fye en Volckje door en door onbetrouwbaar. Deze gegevens kunnen worden aangevuld met enige posten uit rekeningen en verspreide gegevens van elders, die wij in de noten verantwoorden ${ }^{7}$.

Aan Hoofts berichten kunnen wij niet veel gezag toekennen. Hooft heeft wel enige stukken geraadpleegd ${ }^{8}$, maar deze aangevuld met de mondelinge overlevering. Zowel zijn interpretatie van de bewaarde stukken als de mondelinge traditie die Hooft, omstreeks zeventig jaar na de gebeurtenissen, optekende, moeten wij zeer kritisch beschouwen.

Een van de protagonisten, Hendrick Dircksz, was een man van betrekkelijk eenvoudige afkomst. Zijn vader was uit Sloterdijk naar Amsterdam getrokken en had

3. P. TH. VAN BEUNINGEN, Wilhelmus Lindanus als inquisiteur en bisschop (Assen, 1966) 161-162.

4. GRETA GROSHEIDE, Bijdrage tot de geschiedenis der Anabaptisten in Amsterdam (Hilversum, 1938) 127.

5. Signatuur BB 6. Voortaan geciteerd als GA BB 6.

6. c. COMMELIN, Beschrijving van Amsterdam (2 dln, 2e dr.; Amsterdam, 1726) 964-970.

7. Ter Gouw verzuimt veelal om bij de stukken die volgens de hofstijl zijn gedateerd, de datum om te zetten in de gebruikelijke jaarstijl. Daarvoor plaatst hij vele stukken en gebeurtenissen een jaar te vroeg.

8. Enige stukken in GA BB 6 zijn speciaal voor Hooft vervaardigde afschriften of excerpten. 


\section{J. J. WOLTJER}

zich daar een respectabele maar niet prominente positie verworven. Hendrick zelf had in Leuven gestudeerd - hij voerde de meesterstitel-werd in 1525 lid van de vroedschap, in 1526 voor het eerst schepen en in 1539 burgemeester. Hij was zeer begerig naar macht en geld. Met beide was hij - in ieder geval in zijn latere leven ruim bedeeld ${ }^{9}$, maar toch hield de man uit Sloterdijk een ressentiment tegen 'grote heren'. Hij vond dat Bardes te veel aan het Hof verkeerde en 'met die heeren ende groote meesteren te groote kennisse hadde ${ }^{10}$, en tegen Amsterdamse burgers die in den Haag recht hadden gezocht, zeide hij: 'gyluyden hebt in den Hage geweest, ende versoect an grooter meesters dan wy zijn, al waeren u huysen hondertduysent gulden, ende al bracht ghyluyden sacken vol redenen ende turffmanden voll bescheets, soe sullen $u$ huysen nochtans aff ende moeten aff $^{11}$. Een 'wreet, stuer, nydich ende bitter mensche' noemden zijn tegenstanders hem ${ }^{12}$. Als maar de helft waar is van wat deze tegenstanders beweerden, dan was mr Hendrick een gewetenloos man, die zijn vijanden met alle mogelijke middelen bestreed ${ }^{13}$.

De door de Wederdopers in 1535 veroorzaakte troebelen maakten een diepe indruk op hem. De Wederdopers deden toen een aanslag op het stadhuis, die leidde tot een gevecht, 'daerinne doot bleven omtrent xxxiii catholijcke burghers (Godt betert), die hem ter were hadden ghestelt', en waarbij ook Hendrick zelf gevaar liep ${ }^{14}$. Hendrick Dircksz en zijn geestverwanten achtten het toenmalige stadsbestuur mede verantwoordelijk voor deze troebelen, daar dit te mild of te laks was opgetreden tegen de ketters. De angst voor en de haat tegen de ketters zat diep. Nog in 1564 verwezen de burgemeesters naar de gebeurtenissen van 1535 (en van hun standpunt niet geheel ten onrechte: twee jaar later zouden de ketters weer groot rumoer maken). Bij de burgemeestersverkiezing in 1538 had deze 'sincere ende catholycke' partij de macht in de burgemeesterskamer verworven en zij was vast besloten de macht in handen te houden. Het was een kleine, door familiebanden hecht aaneengesmede groep, waarvan Hendrick Dircksz al spoedig de leidende

9. ELIAS, Regentenpatriciaat, 11.

10. Rekest Fye, GA BB 6.

11. A. J. M. BROUWER ANCHER en J. c. BREEN, 'De doleantie van een deel der burgerij van Amsterdam tegen de magistraat dier stad in 1564 en 1565', Bijdragen en Mededeelingen van het Historisch Genootschap, XXIV (1903) 86, art. 39. Vermoedelijk sloeg deze uitlating op een geschil over onteigening van huizen. Vgl. Ibidem, 121-125.

12. Ibidem, 19 .

13. Ibidem, passim. Toen mr Hendrick na de uitspraak van het Hof in 1562 in zijn macht werd hersteld, trachtte hij twee notarissen, Philippus Bisschop en Frans Volcertszoon Coornhert, onder een voorwendsel het notarisambt te ontnemen, omdat zij verklaringen ten gunste van de schout hadden opgemaakt (COMMELIN, Amsterdam, 970-975, vgl. 966 a 1, 2). Zelfs de kinderen van Fye waren niet veilig voor zijn haat. Toen Fye gevangen genomen was, bleef de pastoor aanvankelijk de wekelijkse ondersteuning uitbetalen aan de kinderen van Fye, maar mr Hendrick verbood hem dat! (Ibidem, 969 a 27).

14. BROUWER ANCHER en BREEN, 'De doleantie', 141, art. 86; Verzaemeling noopende het geschil .. Ie zijde, antwoord, punt iii. GA BB 6. Voortaan geciteerd als: Verzaemeling. 
figuur werd. Geborneerd, fanatiek katholiek, met een ressentiment tegen grote heren, een sterke machtsdrift en weinig scrupules, dat zijn de trekken van deze leidende burgemeester van Amsterdam.

Heer Floris Egbertszoon, de pastoor (eigenlijk vice-pastoor) van de Oude Kerk, was in vele opzichten een geestverwant van mr Hendrick. Hij was in Haarlem geboren, had in Leuven gestudeerd en had het baccalaureaat in de theologie verworven. Lindanus achtte hem een onoverwonnen voorvechter van het katholiek geloof, maar Bardes noemde hem een oproerig persoon, die overal twist maakte ${ }^{1 \mathrm{~S}}$. Om dit te bewijzen verwees Bardes naar zijn optreden in zijn vorige standplaats, Edam. Inderdaad zijn in 1546 in Edam drie personen gearresteerd. Simon Poort, de substituut-schout(!), had omstreeks 1535 de naam gehad van de gereprobeerde secte te zijn en zou ook weten wie van de secte waren. In Edam zou hij in de kerk gezegd hebben dat het vagevuur niet bestaat en dat Maria een gewone vrouw was geweest. Toen een heer Gerryt hem hierover vermaande, had hij dit met de $\mathrm{H}$. Schrift willen bewijzen. Tenslotte had hij de preken van zijn pastoor, heer Floris, veracht. Deze laatste aanklacht, gecombineerd met de opmerking van Bardes, wettigt het vermoeden, dat heer Floris de procureur-generaal op de ketters in Edam attent had gemaakt. Simon Poort ontkende de beschuldiging, maar toch werd zijn tong doorstoken, moest hij een boete betalen, drie jaar binnen Edam blijven en alle zon- en heilige dagen naar de kerk gaan ${ }^{16}$. Te zelfder tijd waren Dirck Pieterszoon Smul en Jacob de Geldersman, beiden smid, in Edam gevangen genomen. Twee jaar lang waren zij niet naar de kerk geweest. Dirck had thuis en op de dijk conventikels gehouden, waar ook Jacob kwam, zij geloofden niet in de biecht, sacrament en vagevuur en Jacob had, toen de pastoor (heer Floris) met het sacrament voorbijkwam, dit geen eer bewezen. Beiden"volhardden in hun opvattingen en werden te Amsterdam verbrand ${ }^{17}$. Tegelijk met deze drie personen werd een collega van heer Floris, de pastoor van Koedijk, gearresteerd. Van zijn lot weten we niet meer, dan dat hij aan de bisschop van Utrecht is uitgeleverd ${ }^{18}$. Toen heer Floris uit Edam naar Amsterdam vertrok, keerde in Edam de rust terug ${ }^{19}$.

Een geheel andere figuur was Willem Bardes. Deze stamde uit een van de oudste Amsterdamse regentengeslachten. Hij was vermogend, had in Italië gereisd, verzamelde Romeinse en Griekse penningen en was geen onbekende in de humanistische kringen aan het hof van de regentes Maria van Hongarije. In 1529 was hij voor het eerst en voor het laatst schepen ${ }^{20}$. Toen in 1538 de 'sincere en catholycke' partij

15. Verhoor Bardes f. 11. GA BB 6. Voortaan geciteerd als: Verhoor Bardes.

16. GROSHEIDE, Anabaptisten, 109-110 en de daar geciteerde bronnen.

17. Ibidem, 108-109.

18. ARA Grafelijkheidsrekenkamer, rekening 4466 f. 27 en 75.

19. Verhoor Bardes f. 11.

20. ELIAS, Regentenpatriciaat, 6; TER GOUW, Amsterdam, IV, 390. 
rond Hendrick Dircksz aan de macht kwam, diende Bardes met Jan Ruysch klachten in bij de regentes: Claes Gerritszoon Mattheus (burgemeester in 1538, '40, '41, '43, '46, '50 en '51, overleden in 1553) was een dief en had uit der stede goed gestolen, Claes Loen (burgemeester in 1538, '39, '41, en '45) was een meinedig boef. $\mathrm{Na}$ onderzoek door een commissie werden zij vrijgesproken, maar Jan Ruysch werd op grond van zijn onjuiste aanklacht tot een boete veroordeeld ${ }^{21}$.

In 1542 benoemden de burgemeesters Bardes tot schout. De stad had het schoutambt in pacht, zodat de burgemeesters de schout konden aanwijzen. De benoeming verbaast ons: vier jaar geleden had Bardes ernstige klachten geuit over twee leden van de heersende groep, nu kozen de burgemeesters hem en nam hij uit hun handen dit moeilijke ambt aan.

Een moeilijk ambt was het. Als schout moest hij de plakkaten van de Brusselse regering handhaven, ook als zij de kooplieden en de burgemeesters niet aangenaam waren: zo b.v. over de uitvoer van koren in tijden van schaarste en andere maatregelen die de handel belemmerden. Zolang de stad het schoutambt in pacht had, heeft Bardes geen moeilijkheden gemaakt ${ }^{22}$, en zolang heeft ook Hendrick Dircksz zich weinig aangetrokken van de plakkaten van de keizer, heette het omstreeks $1558^{23}$. In 1550 echter loste de keizerlijke regering het schoutambt en nadat zij tevergeefs gepoogd had om in strijd met de privileges een niet-Amsterdammer tot schout te benoemen, werd Bardes weer schout, maar nu onafhankelijk van burgemeesteren $^{2} *$. Daarna begonnen de moeilijkheden. Na enige jaren heeft Bardes Hendrick Dircksz beschuldigd van knoeierijen in 1545 en 1553 . In 1545 werd het koren in de stad geïnventariseerd. Wanneer er niet genoeg zou zijn, dreigde een uitvoerverbod. Hendrick Dircksz zou de kooplieden hebben geraden meer koren op te geven dan zij hadden. In 1553 zou bij de aangifte voor een belasting van de 10e penning op de huurwaarde van onroerende goederen zijn geknoeid. Volgens de burgemeesters hadden zij alleen rekening gehouden met de extra hoge onderhoudskosten in Amsterdam, iets wat de commissarissen verzuimd hadden. De klacht van Bardes werd overgenomen door de procureur-generaal, maar het Hof verklaarde deze in 1562onontvankelijk in zijn eis ${ }^{25}$, al moest de procureur-generaal wel het recht van Zijne Majesteit in deze zaak bewaren, wat vermoedelijk betekende,

21. BROUWER ANCHER en BREEN, 'De doleantie', 141-142; TER GOUW, Amsterdam, IV, 282-284.

22. BROUWER ANCHER en BREEN, 'De doleantie', 143, art. 96-97. Vgl. TER GOUW, Amsterdam, IV, 434 en schrijven van Hof aan Maria 14-3-1543: Amsterdam heeft de afkondiging van het plakkaat op de 100ste penningfop de uitvoer verhinderd, elders is het afgekondigd (Algemeen Rijksarchief Brussel, Papiers de 1'Etat et de 1'Audience, 1646/1; voortaan geciteerd als Aud).

23. De procureur-generaal in Verzaemeling, 2e zijde xvj.

24. TER GOUW, Amsterdam, IV, 433-438.

25. Vonnis Hendrick Dircksz in GA BB 6. Dat de proc.-gen. in zijn eis niet ontvankelijk verklaard werd, betekent niet, dat de aangeklaagde onschuldig was, het kan ook zijn bij gebrek aan bewijs. Vgl. de proc.-gen. Verzaemeling, 3e zijde. Vgl. BROUWER ANCHER en BREEN, 'De doleantie', 100, 102-106,136 vlg. 
dat hij een civiele procedure moest aanspannen om het deel van de opbrengst van de 10e penning waarover het geschil ging in te vorderen en om de kosten van het proces op de burgemeester te verhalen ${ }^{26}$.

Nog bij een derde zaak is Bardes betrokken geweest. In of kort voor 1555 wendde Willem Snouckaert, raadsheer in het Hof van Holland, zich tot dè bevoegde autoriteiten met klachten over knoeierijen door Cornelis Suys, eveneens raadsheer in het Hof van Holland. In deze lange klachtenlijst, die niet bewaard is, werd o.a. gesproken over geschenken van de regeerders van Amsterdam aan Suys. Bij deze aanklacht speelde ook Bardes een rol. Het eind van het proces was, dat Snouckaert bij sententie van zijn ambt werd beroofd, terwijl de beschuldigde, Suys, niet alleen werd gehandhaafd, maar zelfs tot president van het Hof werd benoemd ${ }^{27}$.

Driemaal heeft Bardes dus klachten ingediend over knoeierijen van magistraten, driemaal is de betrokkene vrijgesproken, tweemaal is de aanklager veroordeeld, maar in beide gevallen is Bardes ongedeerd gebleven. Wat moeten we hieruit concluderen? Was Bardes een ijverig strijder tegen corruptie, maar konden de beschuldigingen niet voldoende bewezen worden? Was hij een querulant die op grond vari loze geruchten anderen aanviel? Het is niet duidelijk. Men krijgt echter de indruk dat Bardes het vertrouwen van de procureur-generaal en de stadhouder genoot ${ }^{28}$, terwijl Hendrick Dircksz zich verdedigde met juridische spitsvondigheden ${ }^{29}$. Het lijkt me in ieder geval onjuist, wanneer Elias de processen van Bardes tegen mr Hendrick alleen maar beschouwt als plagerijen van een aristocraat tegen een homo novus die hij niet kan zetten ${ }^{30}$.

Als schout had Bardes een belangrijke rol te spelen bij de bestrijding van de ketters. Ook hier vinden we na 1550 een verandering in zijn houding. Tot die tijd deed hij naar het schijnt - wat de regering van hem verwachtte. In de eerste zes jaar was dat niet zo erg veel. In die zes jaren velde de Amsterdamse schepenbank slechts vier doodvonnissen over ketters ${ }^{31}$.

In 1547 of 1548 vond te Antwerpen een 'rumoer' plaats, dat voor vele Dopers een reden was om te vluchten. Verscheidenen trokken naar Amsterdam, sommigen na een kort verblijf in Dordrecht. In februari 1549 werden daarop in Amsterdam een vijfentwintigtal personen gearresteerd, misschien op aanwijzing van de Antwerpse

26. Vgl. Margaretha aan Hof van Holland 3-9-1565, Aud. 329 f. 118.

27. Verhoor Suys 1-10-1555, excerpt Aud. 1646/2 e.a. stukken Aud. 326 f. 63, 64,113 en Aud. 1704/1; BROUWER ANCHER en BREEN, 'De doleantie', 156.

28. De stadhouder koos de minst factieuze kandidaten voor de schepenbank in overleg met de president van het Hof en soms in aanwezigheid van de schout (Maximiliaan van Bourgondië aan Philips II 9-12-1557, Aud. 325 f. 246). Blijkbaar beschouwde hij de schout niet als factieus.

29. Verzaemeling, 3e zijde ix, xiiij, xv, xvj, xviij.

30. ELIAS, Regentenpatriciaat, 7.

31. GROSHEIDE, Anabaptisten, 147-155. Aldaar o ok enige lichtere vonnissen over personen die van ketterij verdacht waren geweest. 


\section{J. WOLTJER}

magistraat. Bijzonderheden zijn niet bekend. Anderen, eenentwintig in aantal, konden bijtijds vluchten; zij werden gedagvaard en bij verstek verbannen. Het proces tegen de gevangenen leidde tot niet minder dan veertien doodvonnissen in 1549 en 1550. Een aantal gevangenen werd op handtasting vrijgelaten, hoewel zij toch wel suspect waren ${ }^{32}$.

Omstreeks 1545 of 1546 kwam een zielig mens, Gele Fye, bij de schout. Voluit heette zij Sophie Harmensdochter van Zwolle ${ }^{33}$. Nu is Harman van Zwolle, ook Harman Hoen genoemd, op 28 juli 1535 te Amsterdam als wederdoper terechtgesteld. Het lijkt zo goed als zeker, dat deze Harman de vader van Fye was. Wij horen voor het eerst over Harman in 1533. Toen woonde hij nog in Zwolle. Daar bedreigde hij de pastoor enige malen in zijn huis, sprak de schout in het gerecht onbeschaamd toe en liet de rector van het Broerenklooster een suspect boekje zien. In zijn huis in Zwolle hield hij vergaderingen, hij 'leerde' er en verzorgde de uitdelingen aan de armen. Omstreeks 29 september 1534 vond te zijnen huize een bijeenkomst plaats, waar een vreemd man uit Holland was en verscheidene Zwolse burgers met de nieuwe leer kennis maakten. Kort daarna verliet Harman Zwolle en het hij zich te Deventer herdopen. In april vertoefde hij met andere vluchtelingen in Groningen in de herberg Het Gulden Anker. Daar zei 'Adriaen de propheet uuyt Benscop' tegen hem, dat Amsterdam aan de christenbroeders gegeven was. Er waren wel 5000 broeders in de stad en 'alle de gheenen, die belaeden ofte verjaecht waeren, de zelve zouden derwaerts commen, mits hier een barmhartich volck was, en zouden hier allegader ontfangen worden.' Harman en anderen trokken daarop naar Amsterdam. Hij was wel op de hoogte van de aanslag op 10 mei, maar het schijnt dat hij er niet actief aan deelgenomen heeft. Na de aanslag werd hij gevangengenomen, onder tortuur verhoord en 28 juli 1535 ter dood veroordeeld ${ }^{34}$.

Fye moet tussen de tien en de twintig, vermoedelijk tussen de vijftien en de twintig jaar geweest zijn, toen haar vader werd onthoofd en gevierendeeld, toen de resten van zijn lichaam buiten de stad werden opgehangen ${ }^{35}$. In deze jaren horen we niets over haar, haar broer ${ }^{36}$ of haar moeder Lubbertje. In Groningen was Harman

32. Ibidem, 155-159. Het echtpaar dat in november werd terechtgesteld is misschien later gearresteerd dan de anderen. Vgl. Sonnius aan Viglius 10-11-1549, Aud. 1177/1. Op grond van de verhoren in Amsterdam werden te Woerden zeven arrestaties verricht die weer tot een arrestatie in Delft leidden \{Ibidem, 220-221).

33. Fye werd dus kennelijk uitgesproken als Fie.

34. A. F. MELLINK, De Wederdopers in de Noordelijke Nederlanden 1531-1544 (Groningen, 1953) register i.v.; GRETA GROSHEIDE, 'Verhooren en vonnissen der Wederdopers betrokken bij de aanslagen op Amsterdam in 1534 en 1535', Bijdragen en Mededeelingen van het Historisch Genootschap, XLI (1920) 134-140,141,159.

35. Niet jonger, want in 1537 blijkt ze in staat zelfstandig op te treden (zie hierna), niet ouder, want in 1558 krijgt ze nog een kind.

36. Jan Harmanszoon van Zwolle, schipper, wordt als Doopsgezinde genoemd in 1562. Zie noot 121. 
naar het schijnt zonder vrouw of kind ${ }^{37}$. In 1537 vinden wij Fye in Amsterdam. Zij was op de hoogte van Doperse bijeenkomsten in de buurt van het Cellezustersklooster en elders. Zij meldde deze aan Pieter Cantert, schepen en mr Cornelis Dobbens, schout ${ }^{38}$. Zes arrestaties waren het gevolg. Drie mannen werden 12 april onthoofd, twee jongens en een Geldersman die met ketterse boeken had gelopen werden verbannen ${ }^{39}$.

Jarenlang horen wij weinig over haar. Zij trouwde of was al getrouwd met een man 'van seer soberen regimente', zodat hij herhaaldelijk boete aan de schout moest betalen. Er was echter geen geld om de boetes te voldoen en daarom richtte Fye zich omstreeks 1546 tot schout Bardes. Zij vertelde van haar uiterste armoede en vroeg kwijtschelding van de boetes van haar man, 'daer by seggende, dat sy van Swoll geboren was ende mitsdien wel kende dieversche moertbranders ende sectarissen'. Bardes ging op Fye's voorstellen in en zegde haar een beloning toe als zij moordbranders, Herdopers 'ende ander oproerighe menschen' zou melden. Hij vond Fye wel een lichtvaardige vrouw, maar uit medelijden en omdat ze misdadigers en sectarissen aanbracht gaf hij het arme mens in de loop der jaren wel 300 gulden, ook al bleken haar aanwijzingen dikwijls onbetrouwbaar ${ }^{40}$. Dit bevestigt de indruk, dat Bardes tot 1550 zonder al te grote tegenzin heeft meegewerkt aan de vervolging van de Dopers, al beweerde Fye later dat hij zich al in 1549 niet zo had ingespannen om alle beschuldigden te vangen, als wel verwacht had mogen wor$\operatorname{den}^{41}$.

Op zeker moment, vermoedelijk in het najaar van 1550, vertelde Bardes Fye, dat hij herhaaldelijk en voor geruime tijd naar het Hof te Brussel moest reizen en daarom bracht hij haar in contact met burgemeester Joost Buyck, die van oktober 1550 tot januari 1551 waarnemend schout was, zodat zij ook bij afwezigheid van de schout haar diensten kon bewijzen. Via Joost Buyck maakte zij kennis met de andere burgemeesters, onder anderen met mr Hendrick Dircksz. Zo merkte zij, 'dat die burgemeesters ende bijsonder mr Hendrick Dirckx zoen geen goet hart op de schouttet en hadde, alsoe sij seijden, dat die schoutet te veel ten hoeven reijsen ende met die heeren ende groote meesteren te groote kennisse hadde ende dat hij ten hove all anbrocht wat inder stadt geschiede ${ }^{42}$, sorgende dat hij die stadt bederven soude, mackende oick van hem een luyteriaen ende diergelicke.' Fye was zo gedienstig dit over te brengen aan de schout, die haar immers zo hielp. De schout gaf, volgens Fye, geen aandacht aan haar woorden, maar vond toch wel redenen om

37. GROSHEIDE, 'Verhooren en vonnissen', 135.

38. Copie van rekest Fye, GA BB 6. Voortaan geciteerd als: Rekest Fye.

39. GROSHEIDE, Anabaptisten, 140-142; TER GOUW, Amsterdam, IV, 385-386.

40. Rekest Fye; Verhoor Bardes f. 9vo-10.

41. 'Vonnis Fye', TER GOUW, Amsterdam, IV, 495.

42. Vond de Brusselse regering in wat Bardes vertelde misschien aanleiding om het schoutambt in 1550 te lossen? 


\section{J. J. WOLTJER}

Fye te verbieden verder bij hem thuis te komen en om zijn steun aan haar in de loop van 1551 of 1552 te staken $^{43}$.

In 1552 kwam Fye op het spoor van bijeenkomsten van Dopers ten huize van Volckje Willemsdr en een andere vrouw, Felicitas of Filistis genoemd. Zij rapporteerde ze en in mei kon de nachtwacht een goede vangst doen. Tot de arrestanten behoorde ook Volckje, maar zij en enige anderen werden na verloop van tijd weer vrij gelaten, omdat zij kennelijk niet bij de vergaderingen betrokken waren geweest. De verhoren geven de indruk, dat veel vreemdelingen in het huis van Volckje sliepen, dat zij een herberg, of misschien kunnen we beter zeggen een slaaphuis, hield, waar verscheidene Dopers verblijf hielden ${ }^{44}$.

Fye's tip aan de autoriteiten had afschuwelijke gevolgen. In Amsterdam werden 6 augustus zes mannen verbrand en op 16 januari van het volgende jaar nog een man en een vrouw, terwijl vier dagen later drie personen die herroepen hadden, werden onthoofd ${ }^{45}$. Bij de verhoren was de naam genoemd van Lourens, een snijdersgezel uit Workum. De dag na dit verhoor vertrok een bode naar Friesland en in de eerste helft van 1553 werden daar negen Dopers terechtgesteld, onder wie Lourens. Burgemeester Hendrick Dircksz ging in eigen persoon naar Leiden en Hoorn 'ommte te vervolgen eenige anabaptisten ende diergehjcke vertwijffelde menschen, door hun complicen hier gevangen dedelateerd', en ook in Leiden volgde een reeks doodvonnissen, die duidelijk het gevolg waren van de verhoren te Amsterdam. Uit Antwerpen werd Hans de Drucker genoemd, en 23 september 1552 werd deze te Antwerpen met drie anderen terechtgesteld ${ }^{46}$.

Volgens Fye had zij de Dopers ten huize van Volckje gemeld aan de schout, maar het was Hendrick Dircksz die de beloning aan de commandant van de nachtwacht en zijn tweeendertig wakers uitbetaalde, het was Hendrick Dircksz die geld gaf aan de 'delateurs en de aenbrengers van den anabaptisten' ${ }^{17}$ en het was Hendrick Dircksz, en niet de schout, die naar Leiden en Hoorn reisde.

Behalve de reeds genoemde terechtgestelden moest de Amsterdamse schepenbank nog vier andere gevangenen veroordelen. Volgens Fye wilde Bardes geen doodvonnis 'overmits zijluyden onnozel zijn ${ }^{48}$. Over Stijntje Evertsdr waren allen het eens: verbanning en niet doodstraf was hier op zijn plaats. Over de anderen verschilden echter de meningen. Burgemeester Hendrick Dircksz en burgemeester Symon Martens meenden, dat Aechje 'niet excusabel' was en zij en burgemeester

43. Verzaemeling, 2e zijde xxxix.

44. GA. Rechterlijk archief 270, o.a. f. 222.

45. GROSHEIDE, Anabaptisten, 159-165.

46. J. J. WOLTJER, Friesland in Hervormingstijd (Leiden, 1962) 109-110; GA stadsrekening 1552, f 63 vo en Rechterlijk archief 270f. 259 vo.; P. GÉNARD, 'Personen te Antwerpen in de XVIe eeuw voor het 'feit van de religie' gerechtelijk vervolgd', Antwerpsen Archievenblad, VIII, 420,424.

47. Stadsrekening 1552 f. 94 vo.

48. 'Vonnis Fye', TER GOUW, Amsterdam, IV, 495. 
Pieter Cantert wilden dat Wijbrant en jonge Filistis aan den lijve zouden worden gestraft: in Wijbrant vonden zij niet voldoende simpelheid om anders te handelen. De schepenen oordeelden echter anders: zij spraken over allen een banvonnis. Dit was niet in overeenstemming met het advies dat het Hof van Holland had gegeven. De burgemeesters protesteerden dan ook $^{49}$ en de procureur-generaal van het Hof dagvaardde zes schepenen persoonlijk ${ }^{50}$ zonder dat wij er meer over horen. Dit was sinds 1538 het eerste onmiskenbare verschil van mening over de bestraffing van ketters. Volgens Fye zou Bardes het met de schepenen eens zijn geweest ${ }^{51}$. Het was geen principieel verschil, maar een verschillende beoordeling van de toerekeningsvatbaarheid van bepaalde personen. Maar speelde toch op de achtergrond niet een verschil in mentaliteit mee?

Bij de verhoren in 1552 was de naam genoemd van Annetje Dirksdochter, de bastaarddochter van de Waalse schoolmeester. Zij zou in Haarlem zijn gedoopt, terwijl Lysbeth, de dochter van dezelfde schoolmeester, in Leiden in een bijeenkomst zou zijn geweest waar Gielis van Aken, een bekend Dopers leider, leerde ${ }^{52}$. De Waalse schoolmeester was Dirck van Orliens die zich uit den Haag metterwoon in Amsterdam gevestigd had ${ }^{53}$. Annetje was gehuwd met Cornelis Maertsz, een notaris, eveneens uit den Haag afkomstig ${ }^{54}$. Dit huwelijk was niet zonder problemen. Aanvankelijk waren Cornelis en Annetje slechts per verba depresenti getrouwd, en niet in de kerk. Zekere tijd daarna huwde Cornelis plechtig in de kerk een andere vrouw, maar in zijn vonnis in 1562 heette Annetje toch zijn 'tegenwoordige huisvrouw' en zeer waarschijnlijk was zij dit al in 1553 toen Cornelis Maertsz gearresteerd werd ${ }^{55}$. De vrouw van Dirck van Orliens, Mary Floris, zou, tot verdriet van haar man, conventikels hebben gehouden ${ }^{56}$. Cornelis was ten huize van zijn schoonouders geweest, toen daar zijn schoonzuster Lysbeth en anderen kwalijk spraken over de inzettingen der kerk en het sacrament blasfemeerden. Cornelis' vrouw, schoonmoeder en schoonzuster waren dus, als de berichten juist zijn, allen ketters. Catharina Willemsdr, de dochter van de schout, schijnt tot de kennissen van de familie behoord te hebben ${ }^{57}$.

Cornelis Maertsz sprak met pastoor Floris Egbertsz over zijn schoonmoeder

49. GA, 2e Groot Memoriael f. 43. Vonnissen in Rechterlijke Archieven 567 f. 210.

50. GROSHEIDE, Anabaptisten, 163. De zevende schepen was bij het uitspreken van de vonnissen afwezig geweest.

51. 'Vonnis Fye', TER GOUW, Amsterdam, IV, 495.

52. Rechterlijke archieven 270 f. $261,263$.

53. Verkreeg poorterrecht 24-11-1550. Stadsrekening 1550 f. 23 vo.

54. Poorterrecht 15 maart 1552. Stadsrekening 1552 f. 23 vo.

55. 'Vonnis Cornelis Maertsz', TER GOUW, Amsterdam, IV, 501. Dit vonnis noemt haar Jannetje, alle andere stukken spreken over Annetje, maar de toevoeging dat Lysbeth Dircksdr. de zuster van zijn vrouw was, maakt duidelijk dat hier toch dezelfde persoon bedoeld wordt.

56. COMMELIN, Amsterdam, 965 a.

57. Ibidem, 965 b; vgl. GROSHEIDE, Anabaptisten, 171. 
Mary Florisdr en zijn schoonzuster Lysbeth. De pastoor zei later dat hij hen aangebracht had ${ }^{58}$, maar dat was kennelijk niet de bedoeling van Cornelis. De volijverige pastoor gaf het bericht door aan de magistraat. De schout reageerde niet. Toen de schout echter omstreeks allerheiligen 1553 te Brussel was, liet burgemeester Cornelis Dobbens buiten de substituut van de schout om Mary Florisdr gevangen nemen. Na zijn terugkomst protesteerde Bardes bij het Hof van Holland tegen het eigenmachtig optreden van de burgemeester. Het Hof hoorde beide partijen in den Haag, de procureur-generaal verhoorde Mary en het Hof stelde op 29 november 1553 de schout in het gelijk. De burgemeester mocht geen arrestaties verrichten buiten de schout of zijn substituut om ${ }^{59}$.

Deze beslissing van het Hof spreekt eigenlijk vanzelf, maar wat verbazing wekt, is dat hierna Bardes Mary Florisdr in vrijheid stelde ${ }^{60}$. Was de beschuldiging die heer Floris had overgebracht niet juist? Het lijkt zeer waarschijnlijk, dat Mary wel met ketterij besmet was. Haar arrestatie verwekte in de kringen van de Dopers sensatie $^{61}$. Misschien heeft zij de beschuldiging ontkend en is zij bij gebrek aan bewijs vrij gelaten. Cornelis Maertsz is in ieder geval geschrokken van de gevolgen van zijn gesprek met de pastoor. Aanvankelijk had hij verklaard, dat zijn schoonvader met schreiende ogen bij hem geklaagd had over de conventikels van Mary, later ontkende hij dit en beweerde hij, dat de burgemeesters Mary moesten vrijlaten. Hij wilde zelf garant staan, dat zij na een oproep weer verschijnen zou ${ }^{62}$. Nadat het Hof burgemeester Cornelis Dobbens in het ongelijk had gesteld, ging de schout tot de tegenaanval over. Hij arresteerde ${ }^{63}$ Cornelis Maertsz en klaagde hem aan voor het gerecht van Amsterdam. De aanklacht kennen wij niet, maar vermoedelijk ging het over zijn lichtvaardig 'aanbrengen' van zijn schoonmoeder. Om de achtergrond hiervan te weten te komen wilde de schout hem onder tortuur verhoren. Graag zouden wij weten welke vermoedens Bardes hiertoe brachten. Verdacht hij de pastoor dat hij Cornelis Maertsz opgestookt zou hebben? De schepenbank weigerde de tortuur en sprak Cornelis vrij. Daarop gingen de procureurgeneraal en de schout in hoger beroep en brachten de zaak voor het Hof $^{64}$.

58. COMMELIN, Amsterdam, 968 b 60.

59. Ibidem, 969, art. 30, 965 a onderaan. Memoriael Hof van Holland, Archief Hof 36 f $156 \mathrm{vo-}$ 157.

60. Verzaemeling Ie zijde; vgl. Verhoor f. 15.

61. GROSHEIDE, Anabaptisten, 171; vgl. COMMELIN, Amsterdam, $970 \mathrm{~b}$ onder.

62. COMMELIN, Amsterdam, 965.

63. Vermoedelijk al op 30 november 1553, de dag na de uitspraak van het Hof. Volgens een schrijven van het Hof aan Margaretha van 4-3-1562 had Cornelis toen ongeveer negen jaar gevangen gezeten. Volgens schrijven van 27-9-1559 was hij sinds de laatste november 1556 in strikte gevangenis. Vermoedelijk is in de bewaarde copie van deze laatste brief (het origineel heb ik niet gevonden) een schrijffout geslopen: lvi voor liii. Beide brieven in: TH. J. A. J. GOOSSENS, Franciscus Sonnius in de pamfletten ('s-Hertogenbosch, 1917) 79*, 83*.

64. Maria aan Hof 13-11-1554, Hof van Holland 38 f. 73; vgl. GOOSSENS, Sonnius, 77*. 
Het lijkt duidelijk, dat er na 1550 iets veranderd is in de houding van de schout tegenover de ketters. In 1552 is Hendrick Dircksz de stuwende kracht bij de processen en wenst de schout mildere straffen dan de burgemeesters. In 1553 kon burgemeester Cornelis Dobbens Mary Floris pas arresteren toen de schout afwezig was. Na 1553 zijn te Amsterdam voorlopig ${ }^{65}$ geen doodvonnissen over ketters meer uitgesproken. Drie boekverkopers, die in 1560 gevangen genomen werden wegens de verkoop van ketterse boeken, kregen vrij lichte straffen ${ }^{66}$. In 1564 klaagden de burgemeesters, dat Bardes hun aanwijzingen over ketters zo weinig actief opvolgde, dat deze steeds konden ontsnappen. Een vroedvrouw, Duyff Jansdr, Hans Craeghen vrouw, was in 1544 veroordeeld omdat zij een preek van de doperse Jan Claessen had bijgewoond. Haar was toen verboden langer als vroedvrouw op te treden. Toch was zij weer als vroedvrouw gaan werken en bespotte zij zelfs andere vroedvrouwen die volgens de plakkaten alle pasgeboren kinderen bij de pastoor of de kapelaan aangaven, zodat deze konden nagaan of de kinderen gedoopt werden. De schout deed er niets aan ${ }^{67}$.

Dit alles lijkt in strijd met uitspraken van Bardes zelf in september 1555. Jan Scheyfve, raadsheer in de Geheime Raad, verhoorde toen de schout ${ }^{68}$. Deze verklaarde, dat hij zich steeds moeite had gegeven de ketterij te bestrijden. Om dit te bewijzen wees hij niet alleen op de talrijke vonnissen in 1549-50 en 1552-53 voltrokken, maar ook op zijn activiteiten in 1555. Al lang wist hij uit de verhoren van Dopers, dat Willem Symonszoon Verhouff, alias Willem Trip, 'van de secte' was. Trip, geboren uit den Haag, had zijn vrouw verlaten en leefde sinds omstreeks 1549 met Janneke Laureysdr, geboren uit 's-Hertogenbosch, geprofessiede non in het convent van $\mathrm{Arkel}^{69}$. Bardes vernam nu, dat hij te Weesp verbleef en lichtte de baljuw van Muiden in. Daar deze aarzelde Trip gevangen te nemen, stelde Bardes zich schriftelijk garant voor de gevolgen van deze arrestatie. Toen Trip eenmaal gevangen was, bood hij Bardes aan om alle (!) Anabaptisten in het land aan te geven. Trip noemde de procureur-generaal vier personen in Amsterdam, die daarna door Bardes zijn gearresteerd. Deze vier ontkenden echter het hun ten laste gelegde, ook na confrontatie met Trip. Een vonnis over Trip of over het viertal is niet bekend.

65. Pas in geheel andere omstandigheden, onder Alva, toen Bardes al lang gevangen zat en Hendrik Dircksz schadevergoeding verkreeg voor zijn gevangenschap en proces, werden in Amsterdam weer doodvonnissen over ketters geveld: vier in 1569, twee in 1571 en twee in 1572 (GROSHEIDE, Anabaptisten, 310).

66. Ibidem, 176-178.

67. BROUWER ANCHER en BREEN, 'De doleantie', 150,152.

68. Een uittreksel van de verhoren door Scheyfve GA BB 6. Men krijgt de indruk dat dit uittreksel het gehele verhoor van Bardes bevat, maar dit is niet zeker.

69. Banvonnis 31-7-1553, RA Utrecht, Rechterlijke Archieven 99-2 nr. 174. Tot Trips grote opluchting had het Hof niet geweten dat hij Doper was (Verhoor Bardes). Volgens Bardes kwam Janneke uit het convent van Beek bij Gorcum. 


\section{J. J. WOLTJER}

Het laatste wat we weten, is dat Trip eind 1556 te Muiden gevangen $\mathrm{zat}^{70}$. Alles rond de figuur van Trip blijft raadselachtig en daardoor is het moeiiijk Bardes' houding in dezen te beoordelen. Heeft Bardes Trip als een gevaarlijk individu, als een verleider, beschouwd en daarom zo actief aan zijn arrestatie meegewerkt? Was Bardes niet uit zichzelf zo actief, maar handelde hij op uitdrukkelijk bevel van hoger hand? Heeft hij, nu hij zich bedreigd voelde ${ }^{71}$, willen bewijzen dat hij zijn plicht verstond? De laatste veronderstelling lijkt het meest waarschijnlijk. Ook de episode Trip kan echter de indruk niet wegnemen, dat er bij Bardes na 1550 een groeiende afkeer was van de kettervervolging.

Dit hield geen verband met zijn twist met Hendrick Dircksz. Hendrick Dircksz kon hij hierdoor niet treffen, zichzelf stelde hij echter aan grote gevaren bloot zeker met een vijand als Hendrick Dircksz in de stad. De verklaring zullen wij elders moeten zoeken. Bij de verhoren in 1549 had men de gevangenen uitvoerig ondervraagd over oproerige plannen, maar allen hadden ontkend dat zij of degenen 'die van hun verstand waren' ooit dergelijke bedoelingen gehad hadden. Zij wilden slechts vreedzaam leven en God dienen. De Heer had hun verboden iemand kwaad te doen, zij moesten zelfs weldoen degenen die hun kwaad deden ${ }^{72}$. Het zou meer dan begrijpelijk zijn, als na deze verhoren bij iemand als Bardes de twijfel groeide of het wel juist was deze mensen ten dode toe te vervolgen. Het lijkt dan ook onjuist, als Elias suggereert, dat Bardes, 'de oude ketterjager', in 1564 zuiver uit opportunistische redenen steun zocht bij een groep burgers die later in meerderheid protestant zullen blijken te zijn ${ }^{73}$.

Het is begrijpelijk, dat Hendrick Dircksz en Floris Egbertsz weinig te spreken waren over een schout die zo goed lette op de handel en wandel van burgemeesters, maar van ketters zoveel door de vingers zag.

Ondertussen kwam Fye steeds verder in moeilijkheden. Haar man werd in 1552 'godt betert dootgesteken'. Zij bleef achter met vier kleine vaderloze kinderen.

70. GROSHEIDE,Anabaptisten, 167-176. Tijdens deze processen is ook gearresteerd Otto Barentsz van Zutphen, meester vulder, een tamelijk lang, scheelkijkend man die latijn kende. Na twee jaar gevangenschap kreeg hij van het Hof om ons onbekende redenen remissie \{Ibidem, 176). De inquisiteur Sonnius was verontwaardigd: al was Otto niet herdoopt, hij was besmet met alle mennonitische dwalingen en het Hof had niet eens geëist, dat hij zijn dwalingen zou afzweren: F. soNNius,.4rf Viglium Zuichemum epistolae, p. F. X. DE RAM ed. (Brussel 1850) 23-24.

71. Zie hierna.

72. GROSHEIDE, Anabaptisten, 231-232.

73. Elias beweert, dat Bardes na 1565 schout wilde blijven en daarom de doleantie van 1564 organiseerde (ELIAS, Regentenpatriciaat, 8). Dit lijkt niet juist. In 1560 wilde Bardes het schoutsambt reeds overdragen aan Petrus Zijlacus juris doctor (Hoppers aan Viglius 15-2-1560, Kon. Bibliotheek MS 71C 39,224) en in 1563 aan Willem Maertszoon Calff (Advies Raad en Rekenkamer, Archief Hof van Holland 381 f 167vo-168). Deze laatste maal heette de reden de ouderdom en krankheid van Bardes. Dit lijkt plausibel: hij was geboren in 1496. De doleantie van 1564 had m.i. dan ook niet de bedoeling Bardes schout te laten, maar wel om een geestverwant van Bardes en geen protégé van Hendrick Dircksz met dit ambt te doen bekleden. 
Een jaar later had zij een vrijer, althans zij meende dat zij er een had, maar tot een huwelijk kwam het niet. Volgens Bardes boeleerde zij als weduwe met 'een quidam $^{74}$. In 1558 , toen zij al drie maanden in de gevangenis zat, kreeg zij nog een kind. Toen Bardes zich van haar distancieerde en haar geen hulp meer gaf, was zij overgeleverd aan Hendrick Dircksz en aan de pastoor, die zij als parochiaan of via $\mathrm{mr}$ Hendrick had leren kennen, en die haar ook financieel steunde.

Wij weten niets van de gesprekken van Fye met de pastoor of mr Hendrick, maar het verbaast ons niet, dat de pastoor weldra van Fye vernam, wat hij en de burgemeester vermoedelijk al zo lang hadden willen horen: dat de schout en zijn vrouw voor de oploop van 1535 herdoopt zouden zijn geweest. De pastoor schreef daarop, vermoedelijk midden 1553, een brief aan de hoofdinquisiteur Ruard Tapper om dit belangrijk gegeven onder zijn aandacht te brengen ${ }^{75}$.

Was deze beschuldiging waar? Een dwingende conclusie is hier niet mogelijk. In 1538 werd al verteld dat Bardes doperse sympathieën had, maar de man die dit bericht rondstrooide werd gedwongen het te herroepen ${ }^{76}$. Het lijkt echter niet onwaarschijnlijk, dat de wereldwijze humanist Bardes met een belangstellend, maar skeptisch, oor geluisterd heeft naar sommige Wederdopers, om te weten wat er onder de mensen leefde. De Dopers zouden hieruit - ten onrechte - geconcludeerd hebben, dat hij een der hunnen was.

Heer Floris kende deze geruchten natuurlijk en wellicht heeft hij toen hij met Fye, de dochter van de Wederdoper Harman Hoen, in contact kwam bij haar geïnformeerd of zij er iets van wist. De karakterloze, domme, misschien zelfs debiele $\mathrm{Fye}^{77}$, die zich in het leven trachtte staande te houden door de grote heren naar de mond te praten en hun te vertellen wat zij dacht dat zij horen wilden, zal hem daarop de gewenste gegevens verschaft hebben. Dit is alles hypothese maar er is geen reden om te veronderstellen dat de pastoor aan Tapper bewust onwaarheden heeft geschreven $^{78}$.

74. Rekest Fye; Verhoor Bardes f. 10.

75. 'Vonnis Floris Egbertsz', TER GOUW, Amsterdam, IV, 503.

76. Ibidem,283.

77. Op een gegeven moment vertelde Fye aan Volckje dat er een vergadering van sectarissen in de Cleyne Wingert te Amsterdam zou plaats vinden en zij raadde haar aan om bij een minderbroeder, genaamd 'Hasemoerskint', te biechten dat er veel lutheranen in de stad waren 'ende dat haar verstant was, dat indien dat bij de voors. Volckgen gebiecht hadde geweest den voors. Hasemoerskint, dat hij 't zelve wel voort zou hebben gezeyt ende verbreet an die Weth van Amsterdam' ('Vonnis Fye', Ibidem, 500). Als dat 'haar verstant was', dan was haar verstand maar klein! Het verbaast ons dan ook niet, dat haar moeder eens tegen mr Hendrick Dircksz zei: 'ik wil mijn dochter met mijn nemen naer Swol' (COMMELIN, Amsterdam, 967 a 19), als gold het een kind, hoewel Fye toen al minstens vijf en dertig geweest moet zijn.

78. Fye vertelde zelf, dat de pastoor haar eens vermaand had de waarheid te spreken \{Ibidem, 965 a). Toen in 1555 te Dordrecht onder een aantal Dopers ook een man uit Amsterdam gevangen was, stuurde de pastoor Fye er heen om de man uit te horen of hij niet bevestigen kon dat de schout 'in de oploop was geweest' (Ibidem, 969 b 30, 35). Ook mr Hendrick wilde van Fye en 


\section{J. J. WOLTJER}

Er is ook geen reden om te veronderstellen, dat Hendrick Dircksz hem had opgestookt. We hebben gezien hoe de pastoor in Edam een ijverig ketterjager was geweest, en hoe hij op grond van een toch wel als vertrouwelijk bedoeld gesprek van Cornelis Maertsz, Mary Florisdr en Lysbeth aangaf. Het ligt geheel in deze lijn, dat hij nu Fye's berichten aan Tapper stuurde. Het lijkt ook dat Hendrick Dircksz te slim was om op dergelijke lichte gronden een aanval op de schout in te zetten, want hij wist stellig hoe gevaarlijk lichtvaardige beschuldigingen voor de aanklager waren $^{79}$. Toen de pastoor het balletje eenmaal aan het rollen had gebracht, zal hij zich echter alle moeite gegeven hebben om te zorgen dat het de goede kant op giog-

Omstreeks kerstmis 1553 zou de procureur-generaal uit Den Haag komen om onderzoek te doen naar de naam, faam en wandel van de $\operatorname{schout}^{80}$. Van te voren gingen mr Hendrick en de pastoor nerveus aan het werk om zoveel mogelijk bewijsmateriaal ten laste van de schout bijeen te brengen. Zij lieten Fye bij zich komen en instrueerden haar wat zij de procureur-generaal moest zeggen. Deze zou een brief bij zich hebben (kennelijk door heer Floris, mr Hendrick of een van hun kornuiten geschreven) en Fye moest de inhoud hiervan bevestigen. Als alles goed verliep, zouden ze haar rijkelijk belonen ${ }^{81}$. Fye zette zelfs een val op voor de schout - liet zich althans gebruiken om een val op te zetten. Op 'Sinte Nicolaes avont' kwam zij bij een notaris, Adriaen de Slijper. Zij beweerde dat twee Dopers, Ruth van Naarden en Jan van Hasselt, bij haar thuis gegeten hadden en dat zij dit aan de schout had bericht zonder dat deze maatregelen genomen had. De volgende dag zou zij nu naar de schout gaan en hem vragen waarom hij de Dopers niet had gearresteerd. Adriaen moest dan als luistervink bij de vensters staan om te horen wat Bardes zou antwoorden. Adriaen beweerde, dat de schout hem daarna gevraagd had tegen de procureur-generaal over hem het kwaadste niet te zeggen, maar over dit laatste sprak hij zichzelf bij verschillende verhoren tegen ${ }^{82}$. Het is een wonderlijk verhaal. De kern ervan schijnt waar te zijn. Bardes verklaarde in september 1555 dat twee jaar geleden gesproken was over een eventuele arrestatie van Lenaert, Ruth of Jan van Hasselt, die in het huis van Fye zouden verblijven. Bardes had toen betoogd, dat hij speciale opdracht had om Gielis van Aken te arresteren. Wanneer hij nu bij Fye anderen gevangen nam, zou Gielis nooit meer bij haar komen.

\footnotetext{
Volckje horen, dat de schout voor de oploop herdoopt was. Toen zij beweerden dit niet te weten, werd hij boos en zei, dat zij het wel wisten (Ibidem, 966 b 5). Toen Fye door de proc.-gen. verhoord zou worden, zei mr Hendrick tegen haar, dat zij zich als een vrouw moest gedragen en van de schout zeggen wat zij best wist (Rekest Fye, 2; vgl. Verzaemeling 2e zijde cxj en cxvj).

79. Zie hierna o.a. noot 93 en blz. 198.

80. Rekest Fye spreekt van 1552, maar uit de rekeningen blijkt dat het 1553 moet zijn.

81. Rekest Fye, COMMELIN, Amsterdam, 968 b 10.

82. 'Vonnis Adriaen de Slijper', TER GOUW, Amsterdam, TV, 491-493. Het was vermoedelijk geen initiatief van Fye, COMMELIN, Amsterdam, 967 a 26 en Verhoor Bardes wijzen op burgemeester Cantert als initiator van het plan.
} 
Bovendien achtte hij Fye onbetrouwbaar ${ }^{83}$. Het lijkt dus zeker, dat Fye aan de burgemeesters bericht heeft, dat er Dopers bij haar thuis waren. Of dit bericht waar was, is een andere zaak; later verklaarde Fye, dat ze Gielis van Aken en Jan van Hasselt niet eens kende ${ }^{84}$. Ook achtte het Hof bewezen, dat Fye Adriaen gevraagd heeft bij het venster te luisteren naar het antwoord van de schout ${ }^{8 \mathrm{~S}}$.

Al vaak had Fye (op initiatief van heer Floris?) getracht van Volckje Willemsdr bezwarende getuigenissen over de schout los te krijgen. Ten huize van Volckje waren in 1552 talrijke Dopers gearresteerd, en het lag voor de hand te veronderstellen dat zij het een en ander van de Dopers wist, en dus misschien ook over Doperse relaties van de schout ${ }^{86}$. Volckje en haar man waren arm en van de burgemeesters afhankelijk. Haar man was bierdrager - een stadsambt - en zij woonden op een stadstoren. Fye dreigde nu, beweerde Volckje in 1557, dat Volckje en haar man van de stadstoren gezet zouden worden als zij geen belastende verklaring over de schout aflegde ${ }^{87}$.

De procureur-generaal verhoorde de schout, Fye, Volckje, Adriaen de Slijper, Cornelis Maertensz en vermoedelijk nog anderen. Fye bevestigde bevreesd, bevend en schreiend wat in de brief stond die de procureur-generaal bij zich had ${ }^{88}$.Schout Bardes diende een schriftelijke justificatie in ${ }^{89}$. Toen de procureur-generaal na lange verhoren weer vertrok was weinig meer duidelijk geworden dan dat de zaken bijzonder ingewikkeld waren.

Inmiddels zat Cornelis Maertsz nog steeds gevangen. Was er verband tussen zijn proces en de beschuldigingen tegen de schout? Eén ding hadden beide zaken gemeen : beide waren door de pastoor aan het rollen gebracht zonder dat hij over voldoende bewijsmateriaal beschikte. Misschien is er nog een andere schakel. In het vonnis van Cornelis Maertsz worden-heel ongebruikelijk - twee vrouwen wel aangeduid, maar niet met name genoemd. De ene was de vrouw met wie hij een tijd getrouwd was geweest, de andere is de schrijfster van een brief met 'quade woerden van de sacramenten ${ }^{10}$. In een brief van het Hof is sprake van een andere brief over Mary Florisdr, geschreven door Catrine Willemsdr, de dochter van de schout ${ }^{91}$. Was de briefschrijfster waarover in het vonnis wordt gesproken ook de schouts-

83. Verhoor Bardes f. 8-9,12 vo en 14 vo.

84. 'Vonnis Fye', TER GOUW, Amsterdam, IV, 499.

85. 'Vonnis Adriaen de Slijper', Ibidem, 491-493.

86. Ook in 1535 wordt een Volkje genoemd, waardin in De leeren emmer, waar Dopers bijeenkwamen. Zij vluchtte echter en er is geen aanwijzing dat dit dezelfde Volkje was. GROSHEIDE 'Verhooren en vonnissen', 49,181,194. In 1555 verblijven weer Dopers in De leeren emmer (GROSHEIDE, Anabaptisten, 165).

87. 'Rekest Volkje', COMMELIN, Amsterdam, 970.

88. itófem,968bl3.

89. Verhoor Bardes f. 7 vo.

90. 'Vonnis Cornelis Maertsz', TER GOUW, Amsterdam, IV, 501-502.

91. COMMELIN, Amsterdam, 965. 


\section{J. J. WOLTJER}

dochter? Men zou het haast denken, maar daar staat tegenover dat het wel erg onwaarschijnlijk is, dat de dochter van de schout het sacrament kan blasfemeren zonder dat dit voor haar of haar vader kwalijke gevolgen had.

In januari 1555 liet het Hof, hiertoe gemachtigd door de regentes, Cornelis Maertsz overbrengen naar de Haagse gevangenpoort. De eerste juni veroordeelde het Hof hem tot tortuur. Cornelis ging tegen dit vonnis in hoger beroep bij de Grote Raad te Mechelen, die het Hof in het gelijk stelde ${ }^{92}$.

Ook Fye en Volckje werden weer verhoord en elk verhoor maakte heer Floris en de burgemeester bevreesd dat Fye niet zou blijven bij wat zij heer Floris gezegd had. Zij realiseerden zich ter dege, dat zij door hun lichtvaardige aanklacht grote risico's liepen ${ }^{93}$. Met beloften en dreigementen, met giften en gaven hebben zij gewerkt om van de beide vrouwen de gewenste verklaringen los te krijgen, om te bewerken dat Fye haar belastende verklaringen voor de procureur-generaal zou handhaven. Zij hebben hierbij op bijzonder onbehoorlijke manier misbruik gemaakt van hun maatschappelijk overwicht en van de armoede van de beide vrouwen.

In september 1555 kwam een raadsheer uit de Geheime Raad, Jan Scheyfve, naar Amsterdam en verhoorde Bardes ${ }^{94}$. Het is Bardes gelukt zich vrij te pleiten en nu werden de bordjes verhangen. In maart 1556 liet de procureur-generaal niet Bardes, maar Fye en Volckje arresteren en naar den Haag brengen, vermoedelijk op aanklacht van vals getuigenis en meineed. De beide vrouwen poogden nu zichzelf vrij te pleiten door te beweren, dat zij onder druk van Hendrick Dircksz en de pastoor tot hun valse verklaringen waren gebracht ${ }^{95}$. Hun beschuldigingen tegen de schout waren onbetrouwbaar gebleken, er is geen reden te veronderstellen dat hun aanklacht tegen de pastoor en de burgemeester wel juist was. Het Hof althans twijfelde eraan. Het achtte Fye, Volckje en Cornelis Maertsz 'seer lichte ende vuyle persoenen' en wilde op hun getuigenis geen vonnis vellen zonder dat er aanvullend bewijsmateriaal was ${ }^{96}$.

$\mathrm{Na}$ advies van de Grote Raad te Mechelen achtte de Geheime Raad tenslotte voldoende redenen aanwezig om heer Floris Egbertsz en mr Hendrick Dircksz, pastoor en burgemeester van Hollands grootste stad, te arresteren op verdenking van subornatie van getuigen. De stadhouder Maximiliaan van Bourgondië kreeg hiertoe opdracht. De 4e maart 1558 nam de procureur-generaal beiden gevangen ${ }^{97}$.

De processen duurden lang en het Hof heeft de subornatie van getuigen niet kunnen bewijzen. Na anderhalfjaar gevangenschap overleed Volckje op 18 november

92. HofvanHolland38f.74.

93. COMMEUN, Amsterdam, 967 a 15,969 a 16,970 a 42; Rekest Fye, 3 r 3 . Over de vrouw van der Goude, zie hierna blz. 198)

94. Verhoor Bardes GA BB 6.

95. Rekest Fye; 'Rekest Volkje' (onvolledig), COMMELIN, Amsterdam, 970.

96. Ibidem, 965 .

97. Maximiliaan van Bourgondië aan Philips II 9-12-1557, Aud. 325 f. 246. Hof aan Grote Raad 4-3-1558, Hof van Holland 381 f. 18. 
1557 in de gevangenis ${ }^{98}$, en het duurde nogmaals anderhalfjaar voor het eerste vonnis viel. Adriaen de Süjper, inmiddels ook gearresteerd, werd 23 januari 1559 wegens tegenstrijdige getuigenissen veroordeeld tot geseling en verbanning ten eeuwigen dage". De andere processen, allen met elkaar verbonden, sleepten nog drie jaar voort. Soms klaagde het Hof dat de commissarissen van de bisschop (betrokken bij het proces tegen de priester Floris Egbertsz) de zaak traineerden ${ }^{100}$, maar ook heer Floris zelf maakte gebruik van alle mogelijkheden die het procesrecht hem bood ${ }^{101}$. Weer werden de Geheime Raad en de Grote Raad geraadpleegd en Christiaen de Waerdt, in 1553 procureur-generaal bij het Hof van Holland, maar nu raadsheer te Mechelen, kwam weer naar den Haag om het Hof te assisteren. Het Hof meende dat tortuur van de pastoor nieuw licht op de kluwen van processen zou kunnen werpen, maar het kreeg geen vergunning hiertoe ${ }^{102}$. Tenslotte veroordeelde het Hof op 3 maart 1562 Fye na zes jaar gevangenschap. Op het schavot zou haar tong (waarmee zij vals getuigenis had gegeven) worden afgesneden en daarna zou zij verbrand worden, de straf voor ketters die, nu haar getuigenis onbetrouwbaar bleek, op haar werd toegepast ${ }^{103}$. De volgende dag hoorde Cornelis Maertsz een veel lichtere straf over zich uitspreken: het Hof ontnam hem het ambt van notaris en bande hem voor tien jaar uit Holland, Zeeland en Friesland. Bij dit vonnis had het rekening gehouden met de negen jaar die hij al in gevangenschap had doorgebracht ${ }^{104}$,

Nogmaals drong het Hof nu te Brussel aan op vergunning om de pastoor onder tortuur te brengen, maar tevergeefs. De 16e april 1562 berustte het Hof erin en wees op grond van de gegevens die het zonder tortuur had kunnen verkrijgen, een vonnis dat bijna, maar niet geheel, conform was aan het advies van de Grote Raad. De pastoor moest verklaren, dat hij 'temeraerlicken, indiscretelicken ende min dan te rechte geinformeert zijnde' op grond van mededelingen van Fye de schout en zijn vrouw bij de inquisiteur Tapper had aangeklaagd. Hij moest de kosten van zijn gevangenschap betalen, mocht zich niet meer met de inquisitie bemoeien en werd uit Amsterdam verbannen. Over de subornatie van getuigen zweeg het Hof ${ }^{105}$.

De volgende dag viel ook de beslissing in het proces tegen de burgemeester. Ook

98. GROSHEIDE, Anabaptisten, 133.

99. TER oouw, Amsterdam, IV, 491-493.

100. Hof aan Geheime Raad 14-7-1559, Hof van Holland 381 f. 55 vo.

101. Hof aan Margaretha 27-9-1559, GOOSSENS, Sonnius, $77 *-80 *$.

102. Hof aan Geheime Raad 27-10-1561, Hof van Holland 381 f. 104.

103. 'Vonnis Fye', TER GOUW, Amsterdam, IV, 494-500; Hof aan Margaretha 4-3-1562, GOOSSENS, Sonnius, 82*-84*.

104. TER GOUW, Amsterdam, TV, 501-502 en brief uit vorige noot. Het schijnt, dat Cornelis Maertsz zich na zijn verbanning ergens in het rechtsgebied van het Hof van Utrecht gevestigd heeft (GROSHEIDE, Anabaptisten, 123).

105. 'Vonnis', TER GOUW, Amsterdam, IV, 503-504; Hof aan Margaretha 17-4-1562, Aud. 327 f. 169. 


\section{J. WOLTJER}

hier zweeg het Hof over de subornatie van getuigen, terwijl de procureur-generaal niet ontvankelijk werd verklaard in zijn klacht over fraude bij de inning van de $10 \mathrm{e}$ penning en bij de inventarisatie van het koren in $1545^{106}$. Mr Hendrick begon onmiddellijk voor de Amsterdamse schepenbank een proces wegens injurie tegen Bardes, welk proces al spoedig voor de Grote Raad te Mechelen werd voortgezet. Het was nog niet beslist, toen de troebelen van 1566 begonnen $^{107}$. In 1563 werd mr Hendrick weer burgemeester van Amsterdam.

Het conflict tussen Hendrick Dircksz en Bardes is in zeker opzicht uniek. In de meeste andere steden zouden het Hof van Holland of de Geheime Raad hebben kunnen ingrijpen, de Amsterdamse privileges maakten dit echter onmogelijk. Noch de regentes, noch de stadhouder van Holland, noch het Hof hadden enige invloed op de burgemeestersverkiezingen in Amsterdam. Ongestoord kon Hendrick Dircksz daardoor zijn machtspositie opbouwen. Bij de benoeming van de zeven schepenen kon de stadhouder kiezen uit een veertiental hem door de vroedschap voorgedragen, maar ook dit bood niet voldoende mogelijkheden om een onafhankelijke schepenbank te benoemen. Tenzij de koning met voorbijgaan van de privileges, 'd'auctorité absolute' burgemeesters en schepenen zou aanstellen, zou het niet mogelijk zijn geschikte personen te kiezen, schreef de stadhouder van Holland, Maximiliaan van Bourgondië, op 9 december 1557 aan de koning ${ }^{108}$. Pas in september 1565 zou de Brusselse regering tot een dergelijk krachtige ingreep in strijd met de privileges besluiten ${ }^{109}$.

In andere opzichten was dit Amsterdamse conflict echter niet uniek, en had het een algemeen belang. Na de troebelen van de jaren dertig stuitte de strenge vervolging der ketters aanvankelijk op betrekkelijk weinig weerstanden ${ }^{110}$. In het midden van de veertiger jaren werd nog een groot aantal Batenburgers gevonnist, maar deze uitloper van de Munsterse richting, die zich vooral aan kerkroof schuldig maakte, kon het ongunstige beeld dat velen zich van de ketters gevormd hadden, alleen maar bevestigen ${ }^{111}$. In dezelfde jaren werd echter ook een aantal volgelingen van Menno Simons terechtgesteld en daarna kwamen de slachtoffers in overgrote meerderheid uit deze groep. Vroeger of later drong het tot de gematigde magistra-

106. GABBÓnr. 12.

107. Eis Hendrick Dircksz voor Gerecht Amsterdam, Copie in GA BB 6 nr. 11; Hof aan Geheime Raad 5-9-1562, Hof van Holland 381 f. 129.

108. Aud.325f.246.

109. BROUWER ANCHER en BREEN, 'De doleantie', 63.

110. Wel b.v. in Doornik waar in 1535 geen troebelen geweest waren. Zie: G. MOREAU, Histoire du Protestantisme d Tournaijusqu'd la veille de la Révolution des Pays Bas (Parijs, 1962) 106,149 en passim.

111. J. DE HULLU, Bescheiden betreffende de Hervorming in Overijssel (Deventer, 1899) 246, 291-294. Vgl. J. LOOSJES in: The Mennonite Encyclopedia, I (Scottdale, Pennsylvania, 1955) s.v. 'Jan van Batenburg.' 
ten door, dat de doodstraf voor deze vreedzame Mennonieten barbaars was. In Amsterdam zagen we de houding van de schout in het begin van de jaren vijftig veranderen, zodat na 1553 geen doodvonnissen meer vielen. Ook in het Hof van Friesland won in de jaren vijftig de mening veld, dat men de Dopers niet moest doden, daar zij niets misdeden en alleen maar misleid waren in hun geloof, en ook hier hebben de gematigden na enige tijd hun inzichten kunnen doorzetten, toen Karel van der Nitzen in 1557 president van het Hof werd ${ }^{112}$.

Het proces van Floris Egbertsz is uitvoerig besproken in de Geheime Raad en de Grote Raad. Christiaen de Waerdt, van 1548 tot 1558 procureur-generaal van Holland en daarna raadsheer in de Grote Raad te Mechelen, kende de zaak van haver tot gort. De geschillen in het Friese Hof zijn in Brussel uitvoerig besproken. Het kan niet anders, of in Brussel en Mechelen moet in brede kring bekend zijn geweest dat Bardes in Amsterdam en 's konings Raad in Friesland de ketterij zo veel mogelijk door de vingers zagen.

De gematigden als Bardes en Karel van der Nitzen waren kwetsbaar, want Karel $\mathrm{V}$ en Philips II steunden zonder aarzelen de felle ketterbestrijders. Bardes moest zich in 1555 tegenover Jan Scheyfve, raadsheer in de Geheime Raad, dan ook beroemen op de doodvonnissen die in de voorgaande jaren onder zijn verantwoordelijkheid waren geveld, Karel van der Nitzen en zijn collega's in het Friese Hof legden de eed af op de rigoreuze maatregelen die Philips II van hen eiste, maar zij voerden ze niet uit ${ }^{\mathrm{J} / 3}$.

De 'haviken' hadden een duidelijk program en een duidelijke inspiratie: Hendrick Dircksz, Hippolytus Persijn (1543-1548 procureur-generaal in Holland, 1548-1557 president van Friesland, 1557-1568 president van Utrecht) en hun geestverwanten konden de troebelen van 1535 maar niet vergeten, een inquisiteur als Franciscus Sonnius achtte het zijn harde plicht de godslasterlijke ketterij ten dode toe te vervolgen. De meeste, zo niet alle, gematigden hadden geen program, zij gingen niet uit van een theorie, zij verdedigden niet principieel de tolerantie, maar vroeger of later kwam hun gevoel voor recht en billijkheid, hun gevoel voor maat, in verzet tegen de gruwelijke doodstraf voor eenvoudige lieden die dwaalden in hun geloof. Voorlopig gingen hun wensen niet verder dan wat meer door de vingers zien.

In de ketterprocessen vormde de bewijslast dikwijls een moeilijk probleem. Niet als men een hardnekkig ketter eenmaal gevangen had - dan bleek zijn 'strafbaarheid' uit zijn eigen confessie overduidelijk - maar voor men tot arrestatie kon overgaan en wanneer een gevangene het hem tén laste gelegde ontkende. Door op te komen voor de rechtszekerheid, door met name lichtvaardige aanklachten te bemoeilijken, hebben zowel het Hof van Holland als de Staten van dit gewest,

112. WOLTJER, Friesland, 116.

113. Wel velden zij onder hevige druk van Brussel in 1559 nog drie doodvonnissen. Ibidem, 117118. 


\section{J. J. WOLTJER}

misschien soms nolens volens, maar soms ook welbewust, de ketterbestrijding gedwarsboomd. In 1543 beschuldigde een Goudse vrouw, Marytje Simonsdr, zelf herdoopt, verscheidene poorters en zelfs vroedschapsleden van ketterij. De aanklacht bleek onjuist en de 3e juli 1534 werd zij door het Hof ter dood veroordeeld ${ }^{114}$. Dit was ook in Amsterdam bekend en toen Hendrick Dircksz en Floris Egbertsz na hun voorbarige aanklacht tegen Bardes in moeilijkheden dreigden te komen, trachtten zij Fye tot vluchten te bewegen en mr Hendrick hield haar waarschuwend het voorbeeld voor van 'de vrouw van der Gouw'. Fye heeft deze waarschuwing in de wind geslagen - heeft misschien de moed niet gehad zich in het avontuur van een vlucht te storten - en haar lot kennen wij. Heer Floris werd verbannen, alleen omdat hij 'min dan te rechte geinformeerd zijnde' een aanklacht had overgebracht.

Een lichtvaardige aanklacht, zoals die tegen Bardes in 1553 was ingediend, werd na 1556 in Holland vrijwel onmogelijk. De Staten van Holland stelden in 1555 als een van de voorwaarden voor het toestaan van een bede, de eis, dat voortaan bij processen de getuigenverklaringen openbaar zouden $\mathrm{zijn}^{11 \mathrm{~s}}$. In een (ongedateerde) toelichting wordt dit mede gemotiveerd met de opmerking, dat 'diversche luyden van eeren gecauseert geweest hebbende van heresye ofte andere delicten' hiervan zouden kunnen profiteren, zoals in Friesland, Utrecht, Antwerpen en andere plaatsen waar dit gewoonte was, zou zijn gebleken ${ }^{116}$. De 17 e december 1556 verleende Philips II de gevraagde machtiging om alle getuigenverklaringen voor het Hof van Holland aan de tegenpartij bekend te maken ${ }^{117}$. Een halfjaar later klaagde de Delftse magistraat bij de Staten, dat de pastoor van de Oude Kerk, Jacob van der Goude, arrestatie vroeg zonder opgave van de belastende getuigenverklaringen. De wet van Delft zag geen reden voor een arrestatie, maar de inquisiteurs Tapper en Driutius, die na de dood van de pastoor het proces voortzetten, meenden dat er wel degelijk redenen waren (en terecht: het ging om de bekende rector Geldorpius) ${ }^{118}$. Wanneer men vóór de arrestatie al een groot deel van de bewijzen in handen moest hebben, wanneer een aanklager de openbare mening openlijk zou moeten trotseren, werd een effectieve vervolging wel erg moeilijk. In het ongunstigste geval zou een beschuldigde toch minstens een goede kans krijgen om te ontvluchten. In 1566 meende Philips II, dat 'sans dénunciateurs ou révélateurs

114. c. j. DE LANGE VAN WIJNGAARDEN, Geschiedenis der heeren en beschrijving der stad van der Goude (3 dln; Amsterdam, 1813-1879) III, 216; Hof van Holland 5654 i.d. Het is niet duidelijk waarom dit verhaal voor Hendrick Dircksz zo schrikwekkend was, daar zij, lijkt het, als herdoopte in elk geval ter dood gebracht had moeten worden.

115. P. A. MEILINK, Archieven van de Staten van Hollanden de hen opgevolgde gewestelijke besturen, I ('s-Gravenhage, 1929) regest 606.

116. Aud. 1440/4 nr. 3.

117. MEILTNK, Archieven Staten van Holland, regest 631, vgl. 635.

118. Hof van Holland 38 f. 66 en 1091 op 5-7-1557. Vgl. D. P. OOSTERBAAN,'School en kerk in het middeleeuwse Delft', Spiegelder Historie, I (1966) 150-155. 
toute la reste des paynes qui s'ordonnent est superflue et illusoire, comme demeurant sans effect et exécution ${ }^{119}$.

Deze acties hebben - in ieder geval gedeeltelijk - succes gehad. We zagen al dat in Amsterdam na 1553 geen doodvonnissen over ketters meer geveld zijn, hoewel er toch ketters genoeg waren ${ }^{120}$. In 1562 wenste een Amsterdamse Anabaptist, Jan Janszoon Mandemaker, 'commende tot bekentenisse sijner dwalinghe ende daeraff groot leetwesen hebbende', zich weer met de oude kerk te verzoenen. Zonder dwang noemde hij een hele reeks van zijn 'complicen', een lijst van ruim drie bladzijden $^{121}$. Iemand - wie weten we niet - zond de lijst naar Brussel. De regentes zond deze daarop door naar het Hof van Holland met het bevel de nodige maatregelen te nemen. 'Nochtans, aengesien dat die delatie voers nijet sterck genouch en is, met maniere dat men nijet en valle in gelycke inconvenient als wel eertijts geschiet is', moet u 'met alle discretie' verdere inlichtingen inwinnen ${ }^{122}$.Voor zover ons bekend heeft de hele zaak geen gevolgen gehad.

Het volgend jaar werd Wilhelmus Lindanus belast met de inquisitie in Holland. De les van het proces van heer Floris heeft grote indruk op hem gemaakt. Vijfmaal vertelt hij in de weinige uit die periode bewaard gebleven documenten, hoe deze 'onoverwonnen voorvechter van het katholiek geloof' na vier jaar gevangenschap in ballingschap werd gezonden en dit voorbeeld werkte verlammend op zijn eigen optreden ${ }^{123}$.

Deze stille strijd rond de kettervervolging begon in Holland en Friesland reeds in de vijftiger jaren, terwijl ook velen in de hoogste regeringsorganen, in Geheime Raad en Grote Raad, er van op de hoogte waren. Dit begon al voor de oprichting van de nieuwe bisdommen (waarbij Lindanus en Sonnius een zetel kregen toegewezen), vóór dat de hoge edelen zich tegen Granvelle verbonden, vóór dat de Consulta een overwegende invloed kreeg op de benoemingen (terwijl in deze situatie juist alles er van afhing of op de sleutelposities duiven of haviken werden benoemd). Stellig heeft dit een rol gespeeld bij de op het eerste gezicht zuiver politieke conflicten in de eerste helft van de zestiger jaren, al valt het buiten het bestek van dit artikel om te bepalen hoe groot deze rol geweest is.

119. Correspondance frartfaise de Marguerite d'Autriche, duchesse deParme, avec Philippe II, H. A. ENNO VAN GELDER, ed., II (Utrecht, 1941) 272.

120. 18 februari 1555 schreef Viglius aan Sonnius over een onrustbarende achteruitgang van het aantal communicanten in Amsterdam, zie: c. P. HOYNCK VAN PAPENDRECHT, Analecta Belgica, II (Den Haag) 372-373.

121. Aud. 327 f. 178-179.

122. Margaretha aan Hof 15-7-1562, Aud. 327 f. 191.

123. VAN BEUNINGEN, Lindanus, 181-182. 


\section{Aspecten van de opkomst der textieldrukkerij als grootbedrijf te Antwerpen in de achttiende eeuw *}

\section{A. K. L. THIJS}

De economische opbloei in de Zuidelijke Nederlanden gedurende de tweede helft van de achttiende eeuw* werd te Antwerpen onder meer gekenmerkt door de opkomst van een aantal industriële ondernemingen ${ }^{2}$.

De 'Compagnie Beerenbroek' richtte te Dambrugge bij Antwerpen een textieldrukkerij op, nadat zij in 1753 van keizerin Maria Theresia een exclusief octrooi verworven had waardoor, gedurende 25 jaar, geen nieuwe gelijkaardige bedrijven in de Zuidelijke Nederlanden mochten ingeplant worden. Dadelijk na het verstrijken van het octrooi, in 1778, kwamen echter zowel te Antwerpen als te Gent, Brussel en Doornik nieuwe textieldrukkerijen tot stand, die opgevat waren naar het model van het bedrijf te Dambrugge, De belangrijkste nieuwe drukkerij te Antwerpen was die van 'Christiaan de Visser en Compagnie'. In de loop van de jaren tachtig en negentig werden in de Scheldestad nog verscheidene textieldrukkerijen gesticht. In deze reeks dient vooral het bedrijf van 'Peter Beirens en Compagnie', opgericht in 1788 , te worden vermeld.

Het is evenwel niet onze bedoeling hier de ontwikkeling te schetsen van de onderscheidene textiel- of katoendrukkerijen ${ }^{3}$; we willen alleen, in verband met de opkomst van deze bedrijfstak te Antwerpen, de aandacht vestigen op enkele aspecten die belang kunnen opleveren voor de geschiedenis van de industriële bedrijfsorganisatie.

De katoendrukkerij te Dambrugge en, na 1778, de bedrijven van De Visser, Beirens en anderen onderscheidden zich, van bij hun oprichting, van de textieldruk-

\footnotetext{
* Afkortingen: ARA: Algemeen Rijksarchief Brussel; DCDR, 1-6: Fonds de Cock de Rameyen, Katoendrukkerij 1-6 (Rijksarchief Antwerpen); N: Notariaat; RB: Resolutie-boeck van de Cattoen-druckerije (in particulier bezit); RVF: Raad van Financiën; SAA: Stadsarchief Antwerpen; SR: Schepenregister.

1. H. COPPEJANS-DESMEDT,'Economische opbloei in de Zuidelijke Nederlanden', in: Algemene geschiedenis der Nederlanden, VIII (Utrecht-Antwerpen, 1955) 261-286.

2. F. SMEKENS, 'Ambachtswezen en 'nieuwe nijverheid", in: Antwerpen in de XVIIIde eeuw (Antwerpen, 1952) 64-93.

3. Zie in dit verband: A. THIJS, 'Schets van de ontwikkeling der katoendrukkerij te Antwerpen (1753-1813)' in: Bijdragen tot de geschiedenis, inzonderheid van het oud hertogdom Brabant, LUI (Antwerpen, 1970) 157-190. De achttiende-eeuwse textieldrukkerijen werden door de tijdgenoten meestal als 'katoendrukkerijen' aangeduid, omdat in deze bedrijven voornamelijk op katoen gedrukt werd.
} 